\title{
HISTORICAL OTTOMAN BARRACKS AND AN EXAMPLE OF THEM: DAVUTPASA BARRACK, ISTANBUL, TURKEY
}

\author{
Başak Zengin \\ Dr., Kahramanmaraş Istiklal University, Elbistan Vocational High School, TURKEY \\ zenginbasak@gmail.com
}

\begin{abstract}
Abstract The Military Barracks, which were used during the Ottoman period, were built to exhibit the artistic and architectural style of the period. During the Ottoman rule, with the closure of the Janissary corps, barracks were built for the soldiers with the transition to the regular army. The masonry buildings were surrounded by water channels and cisterns and housed many mansions and palaces. The size of the barracks designed according to the regional characteristics and the number of buildings in them were determined according to the army number of the barracks. When the architecture of the barracks is examined, it is seen that the barracks are not only intended for military training, but also planned by considering many vital functions such as the soldier's resting, training, praying comfortably, and cleaning. In order to transfer many historical buildings to the present, repair and strengthening works were carried out by making use of technology and making damage assessments. In order to transfer many historical buildings to the present, repair and strengthening works were carried out by making use of technology and making damage assessments. In this study, Davutpasha Barracks, which was built during the Ottoman Empire and located in Istanbul, is dis-cussed. The buildings, cisterns, kiosks and pavilions in the barracks are handled as a whole, and their settlement, architectural styles and resistance to external loads are examined and their restorations are mentioned.
\end{abstract}

Keywords: Historical monument, Masonry, Barracks, Istanbul, Ottoman

\section{INTRODUCTIONS}

In order to transfer many historical buildings to the present, repair and strengthening works were carried out by making use of technology and making damage assessments. These studies have gained momentum in the recent period. In order to transfer the barracks symbolizing the history to the present, many historical barracks and their annexes have been examined, necessary repairs and reinforcements have been made and they have been used for different purposes. Repair and strengthening of historical buildings have been the subject of interest and study by researchers both in Turkey and in other countries. Koçak and Kilit, (2010) made the survey of the building, which was built in 1910 in the Antalya region, was used as a school during the time it was built, and was used for military purposes during the war, and made all their analyses and completed the restoration work in line with the report they prepared. Koziorg et al (2014), the structures in the Auschwitz-Birkenau camp in Poland, which symbolizes the tragic memories of the second world camp, 
and the deteriorations on their unit elements were determined and the factors causing this deterioration were investigated. This scope of work; In order to determine the general characteristics of the barracks of the Ottoman period, the barracks built in the Marmara Region were examined, and the Davutpasha barracks were examined in detail. In addition, considering the other barracks, Davutpasha Barracks and the structures inside the barracks were evaluated in detail.

\section{BARRACKS BUILT IN THE OTTOMAN STATE PERIOD}

The gathering places of the military units going to the Balkans and Anatolia were generally located in Istanbul. The barracks, which contain many buildings, were not built only for the purpose of training the soldiers, but were designed to provide education, health care and worship. The important barracks given in Istanbul in figure 1.

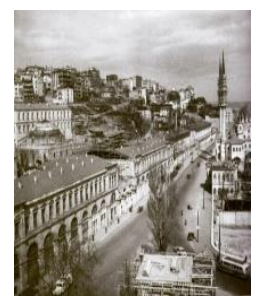

Ball Coaches

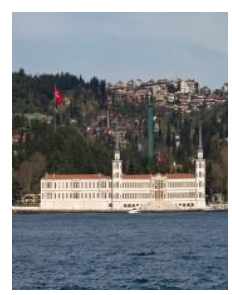

Kuleli

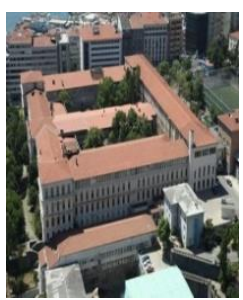

Gümüşsuyu

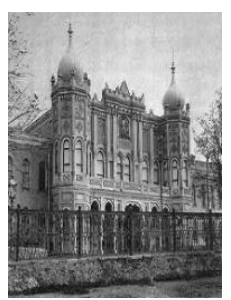

Taksim

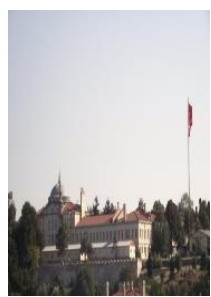

Orhaniye

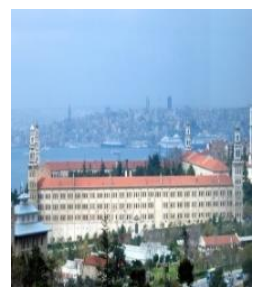

Selimiye

Figure 1. Different Barraks in Istanbul

The general characteristics of the barracks are that they were built in the airy parts of the city and outside the residential areas, with large gardens and a central courtyard in a rectangular plan scheme. It is generally two-storey, and depending on the slope of the land, three or four floors have been increased in some parts. When the plan types are examined, rooms facing the outer garden are seen lined up on one side of the long corridors. The corridors face the large courtyard in the middle and are often illuminated by symmetrical windows. From time to time, various architectural techniques have been used so that the symmetry is not disturbed on the exterior. Especially in the rooms, the direction of the walls as they get closer to the window is changed, ensuring that the window symmetry is not disturbed, and thus symmetry is preserved. The architectural structures of the barracks are generally of the same typology. The purpose of the barracks, which were formed as rows of rooms in order to organize the soldiers, is to create a hierarchical order. The facades of the barracks, which are larger and more magnificent in terms of size than the buildings of the previous period, generally have a neoclassical effect and have a simpler architecture than the palaces. The change in the Ottoman military structure naturally affected the military architecture and the barracks architecture. In these periods, the barracks can be accepted as symbols of westernization in the Ottoman Empire and its military system. The barracks, which are the simplest form of the late period architecture in Istanbul and Anatolia, are the most numerous architectural works of this period. These structures, which are quite large, have a great place in determining the identity of the city (Çetiner, 1996).

\section{DAVUTPASHA BARRAKS}

Davutpasha Barracks, located at one of the high points outside the city walls of Istanbul, has been used as a military area since the reign of Mehmet the Conqueror. Davutpasha Barracks was built as a barracks for the army named Asakir-i Mansure-i Muhammediye formed by Mahmud II. The construction of the building, whose architect is estimated to be Krikor Balyan, started in 1826-1827 and was completed in 1831-1832. The barracks were repaired during the Balkan War and used for sheltering immigrants. Davutpasha Barracks, which has survived to the present day with its original function, completed its military function when it was given to Yıldız Technical University (in 1999) and joined the barracks serving education (figure 2). With this location, it can be said that the building was designed to serve outside the barracks as well. The building, which is out of use today, preserves its plan scheme and many structural elements despite the interventions made in various periods (Tuncer, 2001; Özdoğan and Gümüşay, 2011). 


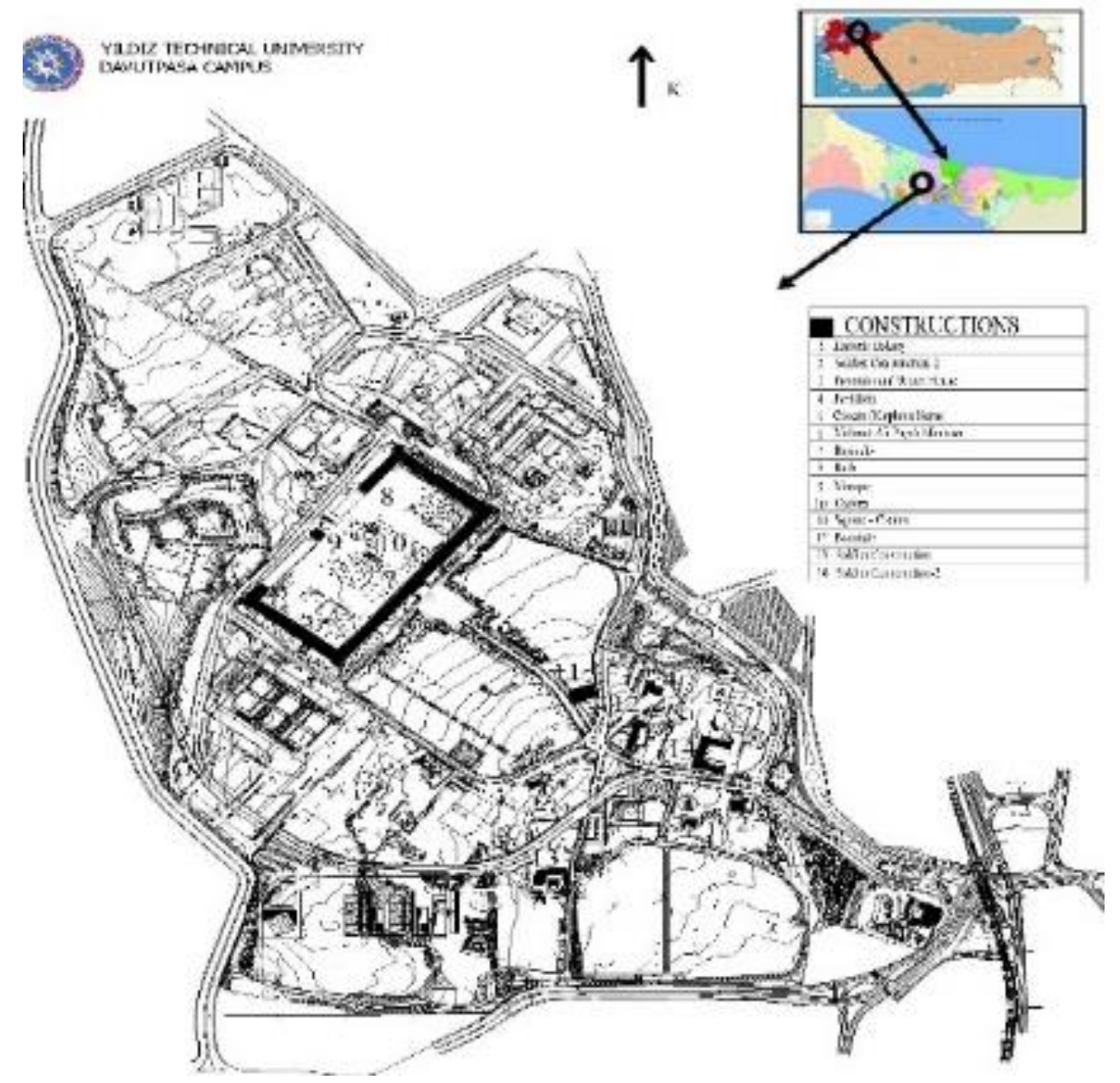

Figure 2 Davutpasha Barrak's location and plan

\subsection{Barracks Building (lejand\#7)}

Of the thirteen barracks in Istanbul, all of which are 18th and 19th century buildings, only two have survived to the present day by maintaining their original function. Selimiye and Davutpasha Barracks, which have survived to the present day with their original function. Barracks building in the 19th century Sultan II. A barracks building was also built by Mahmud (1808-1839), named Davutpasha. Davutpasha Barracks, located at one of the high points outside the city walls of Istanbul, has been used as a military area since the period of Fatih Sultan Mehmet. The waterway, cistern remains and vault fragments left over from a masonry building suggest that this place may have been used as a military area during the Byzantine period. The barracks were repaired during the Balkan wars and used for immigrants, and in the First World War it was used as a hospital (Figure 3).

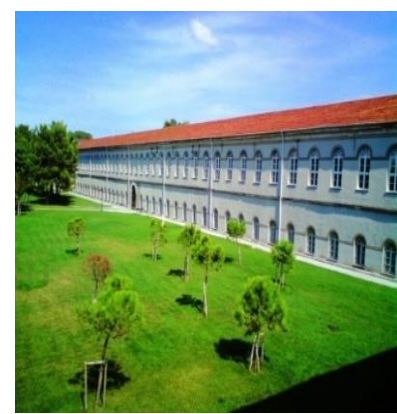

Interior Garden and Front
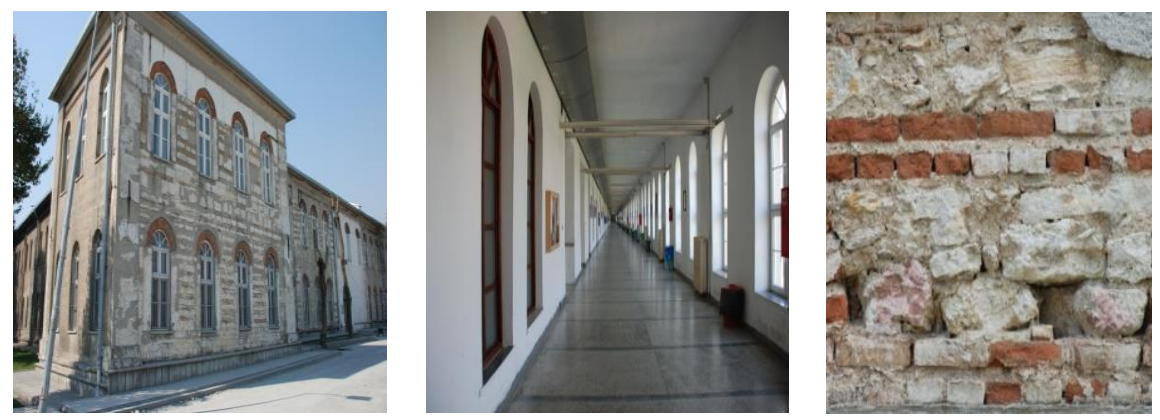

Corner Block

Inside

Wall system

Figure 3. Davutpasha Barracks 
The building, which has undergone many repairs, has a U-shaped shape, the longest side is $362 \mathrm{~m}$ and the other branches are $187.5 \mathrm{~m}$. The plan consists of a corridor running along the entire building and ward rooms opening to this corridor. The ward rooms have a triple window arrangement in their original state. The bar-racks consist of two floors, the ground floor and the 1st floor. The whole building is designed symmetrically with respect to the main entrance. Today, the façade is plastered, but in some of the eastern façade, an alternating wall form is seen in which 1 row of stone and 2 rows of brickwork are formed under the poured plaster (Figure 3). The irregularity of this pattern in places does not allow us to make a definite judgment about whether the original facade of the building is plastered or unplastered (Tuncer, 2001). Davutpasha Barracks, which has survived to the present day with its original function, completed its military function when it was transferred to Yıldız Technical University in 1999 and joined the barracks serving education (Gani 2017).

\subsection{Summer Pavillion (Otağ-ı Huma) (lejand\#4)}

Otağ-ı Huma was built with cut stone on two floors in terms of its architectural structure. The wall thickness is $100 \mathrm{~cm}$. The wall was built with a plain weave (Figure 4). Before the restoration works of the building, which was restored in 2010, were started, survey and restitution projects were prepared. Damages in the building were detected. Material strengths were determined and no reinforcement was required. Clean-ups were made in the places where there were deteriorations. The plaster made on the cut stone in the previous periods was renewed by scraping, the deteriorations in the tiles were repaired, the deteriorations in the flooring were renewed in accordance with the original. The floor on the middle dome on the second floor was re-moved and protected by glass. In the works carried out on the exterior, the reinforced concrete plasters made in the previous period were scraped, the stones where deterioration occurred were replaced and the stone sur-faces were cleaned. The damaged windows in the window were replaced Sheet metal sheets on the roof have been replaced. The door to the bathhouse is closed. The building is currently used as a meeting room.

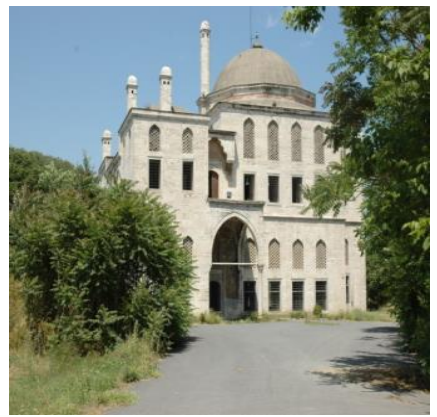

Front

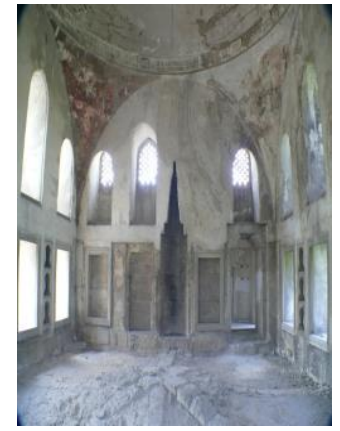

Before Inside

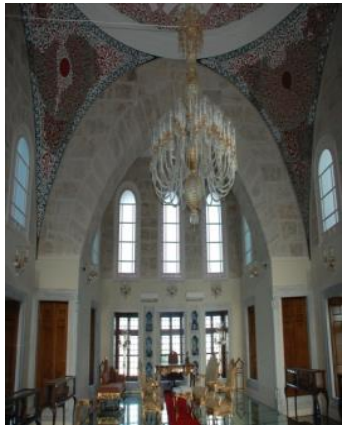

After Inside

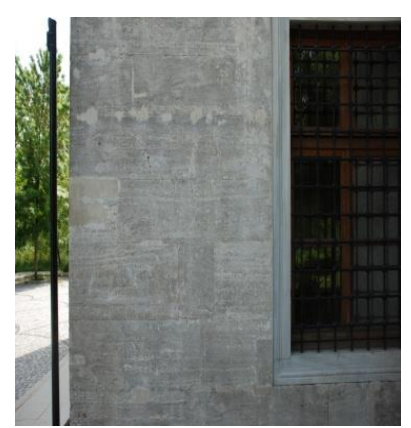

Walls System

Figure 4. Summer Pavillion

\subsection{Bath (lejand \#8)}

The bath, which was designed as a separate building on the north-eastern façade of the barracks, can be entered by climbing four steps from the main building. The main space of the building can be accessed through the dressing room or the cold room located in the barracks structure. To the left of the corridor connecting the two spaces, there are WCs. When the architectural structure is examined, the first prominent features are the 3 rows of rubble stone, 2 rows of filled threshing bricks (Figure 5), the arched windows planned in a certain order, the lead-coated roof system, which is illuminated with an elephant's eye.

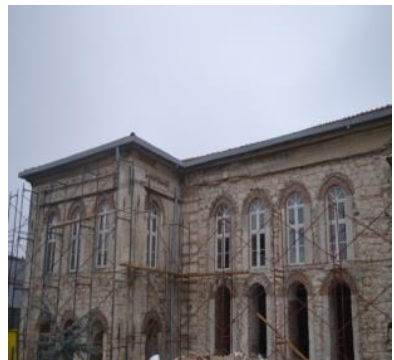

Front

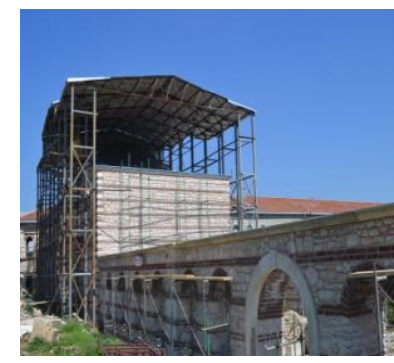

Left Front

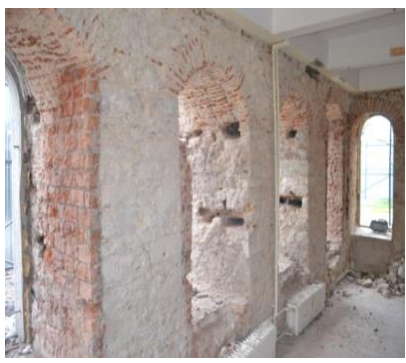

Inside

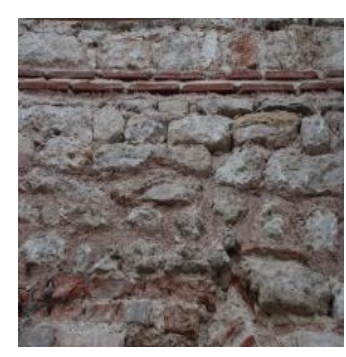

Walls's system

Figure 5. Bath 
No original items such as a basin or similar items that should have been in the main space of the building, whose restoration work continues today. Skeletons with steel constructions were installed throughout the structure and as an additional measure; they were mutually connected with stainless steel tensioners. Material deteriorations were detected with the deterioration in the structure of the building. In order to connect it to Davutpasha barracks, the part that was built later and which damaged the historical structure was removed. First of all, the paints of the historical building inside the barracks were cleaned and the damages were determined. The roof in the warm and hot section has been repaired again. First of all, wooden scaffolding was laid on it, insulation materials were used and sheet metal sheets were laid as in the past. In order to protect the stone dome, a roof was built on it. Later, this area will be covered with tiles. After the structure was strengthened, the detected damages of the structure were repaired. First of all, the stones were cleaned and steel and wooden beams were placed on the broken parts and plastered with Khorasan mortar. Deteriorations and deficiencies in the jambs were repaired with stones and the problems in the arches were solved with beams. Since the historical building will not be used as a bath in its new period, a mezzanine was laid for the new planning and extra reinforcement was made for it.

\subsection{Starboard Lodge (Lejand \#6)}

South of the barracks; Located on the left of the barracks building-south entrance axis, the Sanjak Mansion is $200 \mathrm{~m}$. It is located in the northwest. (Figure 6): Photograph of the entire starboard kiosk). The mansion was built in the first quarter of the 17th century. It is also known as Mehmed Pasha and Ahmet Pasha Mansion. In this building, which has not undergone any restoration, the walls are $74 \mathrm{~cm}$ thick and are built in plain weave the joints in the wall are broken. There is mossing on the stones and melting in some areas and there are abrasions on the surface. The roof of the building is gone. Plants bloomed inside the building.

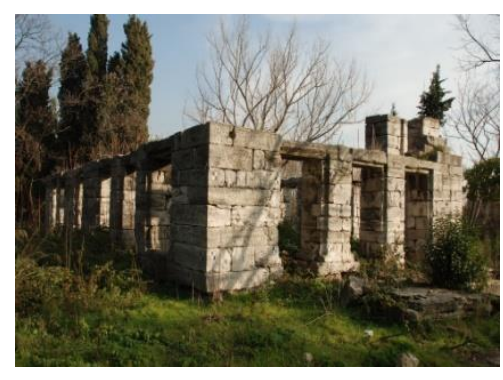

Right Front

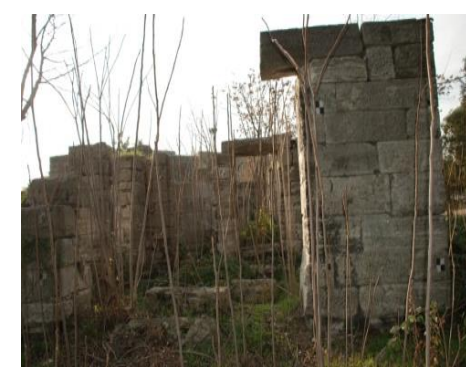

Damage System

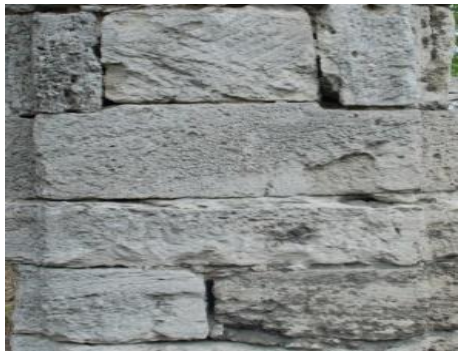

Wall System

Figure 6. Starboar Lodge

\subsection{Historical Bakery (lejand \#1)}

It is located at the southeast end of the Davutpaşa complex, at the lowest elevation of the land. It has a road front; this location is outside of Davutpaşa Barracks; It aims to serve the Rami Barracks. Despite the interventions made in various periods, the building, which preserves its plan scheme and many structural elements, is currently under restoration (Figure 7)

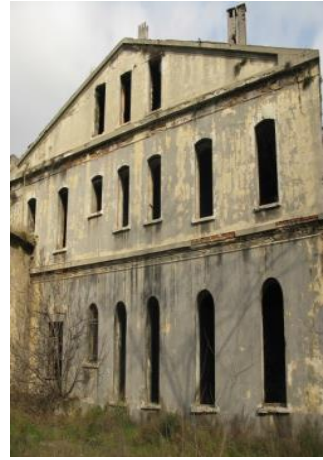

Front

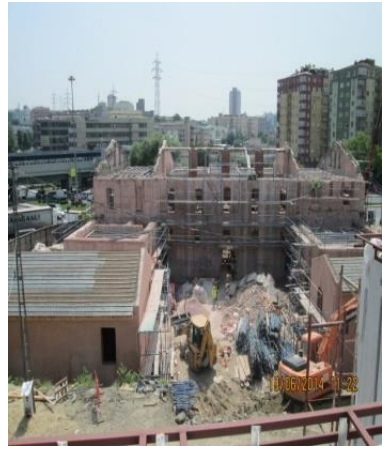

Restoration

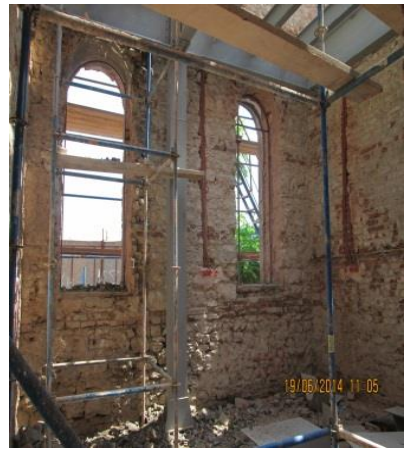

Inside

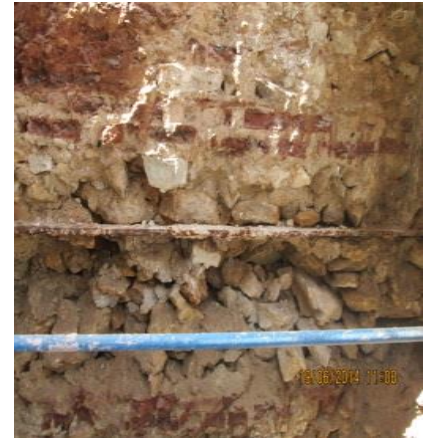

Wall System

Figure 7. Historical Bakery 
It was built on the ' $\mathrm{U}$ ' plan scheme, in the form of an architectural plan extending as two arms on a single floor and encompassing the main building consisting of two floors. Accessed by two main and two service entrances, the ground floor of the building contains a large main space, cooking area, two wide corridors connecting the main structure and the branches on the sides, and the side spaces opening to the corridor. A porch has been built on the entrance façade to easily provide service in all weather conditions. During the restoration work, it is understood that the walls were $75 \mathrm{~cm}$ thick and built in the technique of four rows of stone and two rows of bricks. The floors are emphasized by separating them from each other with the floor moldings on the facades. The windows on the ground floor are designed with arches, and the windows on the first floor are designed with low arches. The windows on the gallery floor are rectangular in shape.

\section{RESULTS}

Historical Davutpasha Barracks extending from the past to the present and witnessing a period and historical event is very important both in terms of architecture and in terms of being the first example of barracks architecture. The importance of the Ottoman sultans' increases as it is the place of entertainment and rest, the place where the soldiers go on expeditions, return from the expeditions and celebrate the wars they won.

In the recent period, the protection and restoration of historical monuments has gained importance, thus restorations of Otağ-ı Huma, Masjid, Bakery and bath buildings have started. The Masjid was opened for use after the restoration, and the other Otağ-ı Huma, Bakery and Bath will be used as a museum after the restoration. Restoration of other historical buildings will be started soon, so that these works can be sent to the future. On the other hand, the barracks are used as a university, and the architecture of the newly built buildings, their height and their proximity to historical buildings are carefully examined by the conservation committees. In addition, the wall, corridor and cistern entrances unearthed during the excavations are carefully unearthed and registered. However, these studies take a lot of time and the cost is extremely high.

\section{REFENCE LIST}

Çetiner, Z., (1996), Davutpasha Barracks and Its Place in Istanbul Barracks, YTU, Institute of Science, Master's Thesis, İstanbul, Turkey.

Gani E., (2017) Analysis of historical Davutpasha Barracks supported by dynamic measurement under horizontal and vertical loads, YTU, Institute of Science, Master's Thesis, İstanbul, Turkey.

Koçak, A., Kilit, Z., (2010) Restoration and Strengthening of a Historical Structure in Antalya - Turkey. Advanced Materials Research, 133-134, 575-584.

Koziróg A., Otlewska A., Piotrowskaa M., Rajkowska K., Nowicka-Krawczyk P., Hachułkab M., Wolskic G., Gutarowskaa B., Kunicka-Styczyńskaa A., Libudzisza Z., Żakowskaa Z., Żydzik-Białekd A.,2014. Colonising organisms as a biodegradation factor affecting historical wood materials at the former concentration camp of Auschwitz II - Birkenau. International Biodeterioration \& BiodegradationVolume 86, Part B, January 2014, Pages 171-178, 2nd International Conference on Biodeterioration of Wood and Wood Products, Tartu, Estonia

Özdoğan, Ş., and Gümüşay, Ü., (2011). Three-Dimensional Modeling of Davutpaşa Campus Historical Artifacts and Inquiry in GIS Environment, TMMOB Harita ve Kadastro Mühendisleri Odası, 13. Turkey Map Scientific and Technical Congress, Ankara.

Tuncer, F., (2001)., Davutpasha Barracks structures, Proceedings of the 11th International Congress of turkish art, EJOS, IV, The Netherlands, August 1999, No:43, 1-24

Vasconcelosa G., Polettia E., Salavessab E., Jesusc A., Lourençoa P., Pilaond P., (2013). In-plane shear be-haviour of traditional timber walls Engineering Structures Volume 56, November 2013, Pages 1028-1048 Historical Constructions. Guimarães. Portugal. 